\title{
Chapter 12: West End Musical Theatre and the Representation of \\ Germany
}

\section{Len Platt}

\section{Kultur and West End theatre}

This chapter is concerned not with the physical transfer of shows between London and Berlin but with a broader and more flexible concept of transference that centrally involves travel and appropriation in the representation of race and nation. It makes further claims for a musical theatre that, as well as being 'just entertainment', played an important role in ceremonialising cultural attitudes and values across the period. Again the contemporaneity extended well beyond casual allusion to contemporary events. Some reference is made to configurations of Britishness on the Berlin stage, but the greater emphasis is on how Germany and Germans were represented in West End musicals. This is simply because, for all the alleged 'Anglomania' of Berlin in the early-twentieth century, ${ }^{1}$ the representation of Germany appears to have been of greater significance and interest to the makers of musical theatre in the West End than Britain was to the producers, writers and performers in Berlin. Berlin musical theatre made passing references to Britain and the British, in the German version of The Geisha for example and in a number of Metropol-Theater revues. It was also every bit as patriotic as the West End during the war, which meant that Britain and the British figured in particularly hostile ways in the early days of the conflict, just as Germans and German culture did in London musical theatre at the same time. But West End investment in 'Germany' was more sustained across the period and extended to the extreme of producing entire plays built around nothing less than concepts of Germany or, as we have seen, more typically 'Austria'. 
Some of these reproductions, like The White Horse Inn, were imported, but many were homegrown affairs, like The Girls of Gottenberg. 'Germany' also played a particular part in West End musical retro in the 1920s and 30s, in shows like Nöel Coward's Bitter Sweet (1929) and Ivor Novello's The Dancing Years (1939). Another Coward show, Operette (1938), was set in the West End and reflected back on the glory days of English musical comedy. But for all this nostalgia and seemingly local version of things, an exoticised German identity became centrally important, entangled not only with ideas of cultural value, an association that was standard, especially in relation to musical composition, but also with all the labour, pain and intensity of performance as represented by the German diva Liesl Haren — played in the original production by a great German performer, Fritzi Massary. ${ }^{2}$

What made the idea of Germany/Austria so much more compelling to West End audiences than the idea of Britain in Vienna or Berlin-even, indeed, particularly, after the First World War? John R. Davis, a historian of German influence in Britain, argues somewhat controversially that,

of all the parts of the world the Victorians were interested in, it might reasonably be claimed the area known as Germany was most important .... German and German matters figured significantly in a large number of areas in Victorian life and thought. Interest was sustained in Britain throughout Victoria's reign. In many respects, issues relating to Germany can be said to have preoccupied the Victorian mind. ${ }^{3}$

Davis goes on to show how curiosity grew in British intellectual circles in the nineteenth century — at a time when Britain and Prussia were political and military allies against the French. German philosophy, literature, theology and, perhaps most centrally, music, were viewed with awe in the first half of the nineteenth century. 
Figures like Thomas Carlyle, Sir Walter Scott, George Eliot and the English Romantics — all fascinated by German culture-were symptomatic of a much broader engagement. In part through the German influence on philology and research practice generally in the humanities, this extended into hugely influential raciologies, which became, in various guises, common currency in European life.

That broader process of cultural exchange was hardly one-way. As Davis points out, while Britain venerated Germany for its high culture, German intellectuals admired Britain for its constitutional monarchy. Romantics like Johann Gottfried von Herder responded to what was perceived as the humanist dimensions of British literature. Thus the obsession with Shakespeare, a figure lauded in Germany for 'harmonising Classical principles with human reality'; the interest in Irish Celticism and the Literary Revival; the fascination for 'The Scottish tales of Ossian', which were 'greedily absorbed for their perceived innocence and naturalness' and 'British Gothicism'.

For all this mutual regard, however, there can be little doubt that the energies of a relatively new and emergent cultural, political and economic centre were compelling, and often alarming, in ways that an old Empire defending its authority in the world struggled to compete with-one reason why Germany retained a disproportionate interest for Britain.

This traditionalist version of Anglo-German cultural exchange, typically operating at the level of high culture, has some resonance in relation to popular musical theatre cultures. As many contributions to this collection illustrate, contemporaries insisted on situating the West End musical in unfavourable relation to the German version on grounds of music quality. Writing about Oscar Straus's musical adaptation of George Bernard Shaw's Arms and the Man, Der tapfere Soldat, 
E. A. Baughan explained the success of the show in Vienna and Berlin. 'Its story has a clear idea', he wrote 'and the music is on a higher level of workmanship than that of any of our native musical comedies. ${ }^{5}$ Frank Washburn Freund told the same story about the same show:

In its new dress this work had great success in Vienna, where its gaiety and freshness were much admired, and the music was said to be full of clever and delicate parody. The critics called it the first successful attempt at elevating the tone of musical comedy, by doing away with the single numbers which have no connection with the plot of the piece. Thus Shaw is helping to raise German musical comedy — and, who knows, perhaps English also! - to a new and better life. Who would have thought that of him. ${ }^{6}$

Featuring the London version of Lehár's Gypsy Love (1912), the Play Pictorial pointed out with some regret that 'greatly as the musical public has increased its appreciation of good-class music it is still unable to frankly accept an operette that is not well punctuated with the humorous sallies of the light-hearted comedian. To that end', it continued, 'the plot [of Gypsy Love] has to be treated with an inventive mind, and it is not paying Captain Basil Hood an out of the way compliment in saying that he rather ranks with the original authors than as a mere adapter of the libretto. ${ }^{, 7} \mathrm{~A}$ year later, Baughan was wishing that 'a librettist of genius could be discovered' to give 'this form of art...a new impetus. The public wants something new and better than it has been given' and in 1914 Baughan again saw some hopeful signs. 'Musical comedies', he noted, 'are improving every year. The music is more ambitious and the low comedian does not have everything his own way....The public has taken a great fancy to the finished and workmanlike scores of Viennese composers. ${ }^{8}$ At one level, then, and certainly as far as the theatre critics were concerned, German musical 
theatre, through its association with high quality and serious music, represented the tone to which West End musical theatre aspired. It was in part this perspective on cultural and aesthetic value that led to West End producers looking towards the Continent for the next success.

\section{'Capturing the very spirit': The Girls of Gottenberg}

Not entirely immune to the draw of Germany's high cultural status, this was, however, a demotic culture, shaped by the immediacy of the contemporary event. It was also a modern one, concurrent in its rise with Germany's fully-fledged appearance as a world power after unification and fast-accelerating economic and military importance. For all these reasons, musical theatre was highly sensitive to the rival versions of national destiny that shaped Anglo-German relations. Germany's involvement in the Boer War, for example, produced a particular bout of anti-German feeling in 1896 which spilled over in a dramatic way when a song entitled 'Hands Off' was inserted into An Artist's Model (1896), apparently in a deliberate attempt to capitalise on 'rampant patriotism'. 9 The Times gave a full report of the affair, illustrating just how politicised the musical theatre space could become, especially when national pride was at stake:

A singular scene occurred on Saturday night at Daly's Theatre during the performance of An Artist's Model. It had been announced that Mr. Hayden Coffin would sing for the first time, a patriotic song entitled 'Hands Off!' The house was crowded. In the song as originally written several references were made to the German Emperor, one line running 'Let the pinchbeck Caesar strut and crow,' and so on. At the last moment the Lord Chamberlain intervened, it is stated at the instance of the Colonial Office, and refused to allow the song to be 
sung in that form, with the result that several material alterations were made. During the first part of the play every reference made to the Transvaal was the signal for loud outbursts of applause, the name of the German emperor being loudly hissed and hooted, while cheer after cheer greeted the names of the Queen, Dr. Jameson, the Chartered Company, and Mr. Chamberlain. Several times cries of 'Three cheers for Dr. Jameson' and 'Groans for the Kaiser' were raised in the gallery and responded to. The song was introduced in the second act, Mr. Coffin being surrounded on the stage by a number of soldiers. The chorus, as follows, was received with great enthusiasm:

Hands off each of you! Hands off, all!

Boers boast and Deutscher brags; Britons hear the call!

Back to back the world around, answer with a will -

England for her own, my boys! It's 'Rule Britannia' still.

As the chorus ended the soldiers drew their swords to the salute. The audience responded with continuous rounds of cheering. ${ }^{10}$

Sometimes seen as an apolitical culture, there were times when musical theatre became deeply engaged in such direct ways. More typically, however, musicals maintained a relatively low level of comic ridicule, often targeted specifically at the German Emperor - a figure whose representation was routinely monitored by the offices of the Lord Chancellor throughout the period-but sometimes levelled more generally at Germany's status in high culture. ${ }^{11}$ Here the intellectual achievement held in such great esteem by the high cultural establishment was rendered suspect and often reproduced as absurd pontificating. Thus the kind of comic business illustrated in the following exchange between a feminised Frenchman, Count Marie de Lafleur, 
and the pompous German, Professor Phunckwitz. It occurs in the Edwardes musical comedy The Messenger Boy (1900):

Phunk: I vill talk to Hooker, don't it?

Lafleur: Je suis français. Can I not talk?

Phunk: Yah! You talk but vat is in him—mit your English is broken so.

Lafleur: Oui-I break all e English I can. Revenge!

Phunk: I was spoke the English like a nature-ain't it? ${ }^{12}$

The German intellectual, with his unparalleled status in linguistic scholarship, became ousted by a ridiculous mutilator of language, a rendition echoed in many shows in the period, even in ones that were imported from Germany-in, for example, the London production of Jean Gilbert's Die Kino-Königin where a German waiter is characterised by his poor, twisted English. It figured again in the most sustained attempt to stage Germany as a West End musical spectacle in the early period-The Girls of Gottenberg.

This show provided very good illustration both of musical comedy's topicality and the nature of its interest in Germany at this time. Produced in 1907, it was based on the escapades of one Friedrich Wilhelm Voigt, a small-time crook and con man who a year earlier had succeeded in convincing a group of soldiers in Berlin that he was a captain in the army. In this disguise he travelled with his 'company' in tow to Köpenick, a town east of Berlin, where he charged city hall officials with corruption, arrested them and 'confiscated' 4,002 marks and 37 pfennigs. His deception was discovered and Voight was caught, tried and sentenced to four years imprisonment, although he was eventually released on the orders of the Kaiser after serving just under two years, a reflection of the fact that for large sections of the German public the 'Captain of Köpenick' had become a folk hero, celebrated for his daring and what 
was perceived as comically outrageous cheek. For the English press, as might be expected, the case had a very different resonance, confirming stereotypes of a perceived German obsession with militarism and excessive respect for the authority of the uniform. The Illustrated London News for 1906 noted the obvious ironies:

For years the Kaiser has been instilling into his people reverence for the omnipotence of militarism, of which the holiest symbol is the German uniform. Offences against this fetish have incurred condign punishment. Officers who have not considered themselves saluted in due form have drawn their swords with impunity on offending privates. ${ }^{13}$

This was the event which led to George Grossmith Jnr. and L. E. Berman's book for The Girls of Gottenberg. In the Gaiety version, a barber valet, Max — played by the comedian Edmund Payne - on the instructions of his master, Prince Otto, impersonates an Imperial envoy in order to get Otto's regiment, the Red Hussars, barracked in Gottenberg, where fulsome opportunities for pleasure offer an attractive billet. Max, however, goes way beyond this remit and finds himself operating under his own authority to order the Town Clerk and Burgomaster of Gottenberg to prison. Not least, this confinement allows Max to pursue without restraint his passion for the Burgomaster's oversized daughter.

The conceit of a more thorough and complete reproduction where characters on stage were performed by British actors as if they were German, meant that in this show the English language became notionally German, at least for the high-ranking officers of the Red and Blue Hussars. For all this apparent erasure of difference, however, space was still reserved for ridicule and national rivalry. In the song about girls, for example, English girls are favoured over German girls, the latter being represented as scruffy intellectuals. The standard buffoonery is evident in the 
character of the joke sergeant, Brittllbottl, speaking a conventional stage German. Just as in The Messenger Boy, it turns on fractured words and comic stage accents. Moreover, in this show the famous university traditions of Germany also suffer the indignities of comedic reduction, being rendered in terms of other familiar caricatures - militarism, drinking cultures and a tendency for German women to be domineering and masculine. The song of a woman's college demonstrates all these associations:

Hoch! hoch! hoch! for the girls of Gottenberg College,

Hither the German girls will throng.

Fair and strong,

Raising the song!

Hoch! hoch! hoch! for the band

Who join in sport and knowledge,

Wielding like men

Sabre and pen for fatherland. ${ }^{14}$

[INSERT ILLUSTRATION 14]

[CAPTION] Stereotypes of Germany: The Girls of Gottenberg, 1907

The Girls of Gottenberg indulged in the kind of stereotypes familiar in pre-war West End musical comedy. But this was not the only sense in which it diverged from the Victorian veneration of German culture. The further instinct behind shows like this, as ironic as it may seem, was rather more compatible with other high-profile Victorian dispositions - to create spectacles which balanced 'amusement' against 'instruction', for example. This was the ostensible justification behind West End 
interest in other cultures, European and otherwise. China was reproduced in $A$ Chinese Honeymoon (1901), India in The Blue Moon (1904), Ceylon in The Cingalee (1904), as well as Holland in Miss Hook of Holland (1907), a historicised Scotland in The Gay Gordons (1907), the French Riviera in My Mimosa Maid (1908) and so on. The endless search for attractive and commercial innovation, as well as the satisfaction of British national pride, was intimately bound up with the staging of cultural difference as educational enlightenment. This dimension of musical theatre in the early period, ostensibly anthropological and often lauded for its 'realism', was at the same time a triumphalist celebration of cultural authority and in this sense related to exhibition cultures of the same period. Thus a show like The Geisha was applauded for its 'authentic' interpolation of Japanese instrumentation: for its clothes, 'all worked by hand' and 'exported from Japan' and generally for capturing 'the very spirit of Japan'. ${ }^{15}$ The Girls of Gottenberg, with its cartoon-like version of 'Germany', was partly understood in similar terms, as a spectacle to be judged by its powers of reproduction. Reviewing this show, the Times observed in a thoroughly ambiguous comment that the scene painters 'Messrs Joseph and Phil Harker ... [had] studied German lithographs (the cheap kind; made for schools) to some advantage.,16

In this early period, then, the representation of Germany on the West End stage was contradictory, in a number of ways. On the one hand it confirmed a British musical theatre characterised in part by the comic dimensions that often involved laughing at other cultures, but perhaps especially at Germany which had particular currency in this respect. Less transparently, the investment required to stage the spectacle of the other in such extravagant dimensions was tied in to notions of cultural authority and maturity, where the fast-developing entertainment sites of the world were invested with pseudo-educational responsibilities. At the same time, the attempt 
to align musical theatre with high-status music cultures reflected one of the constant themes in the development in West End musical theatre since the mid 1890s-its drive for respectability: the grip over that middle ground of culture where the highest profit margins were to be had.

\section{'Germany' in the First World War-the West End revue}

The Great War produced a new hostility toward ethnic and national difference in popular culture, understood by some historians as part of a coarsening, running counter to the predisposition for cosmopolitanism and inclusivity which once characterised musical theatre. Otte is suggestive here when she argues that ‘Germany's entertainment scene was economically and artistically impoverished by the war, and employment opportunities [for artists] were drastically reduced, not least because Jewish enterprises had collapsed in great numbers. ${ }^{17}$

There can be little doubt that patriotism defined musical theatre in the war years. Writing in the Stage Year Book for 1916 under the title 'The War and the Stage', Bernard Weller detailed the substantial contributions made by the theatre industry to the war effort, not least through theatre people volunteering for the armed forces, but also 'through its art' which 'has bodied forth the call of patriotism'. He continued, 'the stage, through its performances, has contributed enormous sums to the War funds. It can rightly be proud of all this practical service, which has also been freely supplemented in other ways.' 18 Songs like Ernst Lissauer's 'Hassgesang gegn England' ('Song of Hate Against England'), 'England Remember' and 'Don't Forget the Navy' combined with tableaux such as the one of 'Our Fleet' in revues like Razzle Dazzle (1916) to produce the characteristic flavour of musical entertainment in both sites - certainly at the beginning of the war-and here the comic representation of 
national and racial stereotypes did, indeed, take on a new edge. In West End revuea form of musical theatre which, far from declining in wartime, grew in popularitynew design elements and innovative fragmented forms combined with a differently radicalised dispensation for engagement with the racial other. ${ }^{19}$ Jewish identities typically became mixed up with notions of the Germanic and the Russian to produce a standard, if often confusing, alien identity of the West End stage.

C. B. Cochran's revue As You Were (1918) is illustrative in this respect. It is set in a world of nouveau riche ascendancy where 'Solly Abrahams' has become elevated to 'Lord Nose' and one of Lady Boost's guests is 'Alienski Brightonvitch'— 'the man who invented the Season Ticket. Married one of the Maidenyids'. The central conceit of the show involves 'transport pills' which, far from embracing modernity as in early musical comedy traditions, take the patient back to 'the good old times'. It is by this means that the play's central figure, Lord Boost, is returned in scene 3 to the 'Court of the Hunzollern, Potterdammerung Period: Medieval'. Here he crosses swords with 'Hunzollern':

Hunzollern: Go tell thy people, Englishman, that on the thirty-first day of February, in this year of Warlord, Maidenhead will be taken by the Hohenzollern.

Boost: $\quad$ Nothing doing! It's already been taken by the Cohenzollern.

Hunzollern: Then we must needs give the devil his Jew. ${ }^{20}$

The telling conflation of Jew and German in the composite 'Cohenzollern', associated with the idea of invasion, was characteristic of a wider tendency to construct 'aliens', of whatever kind, as 'indigent Jews' which appears to have transferred over to the musical theatre stage in the war years. In his cultural history of the Alien Immigration Act (1905) and its impact on literature, David Glover quotes from a reminiscence of 
life in the East End of London where 'in 1901 a "shabbily dressed man", piqued at having to sell the non-Jewish anarchist Rudolph Rocker a pair of phylacteries, informed his interlocutor with unshakeable confidence that he must be a Jew, because "all foreigners are Jews". ${ }^{21}$ A later scene in As You Were, set in a primeval forest, makes similar associations. It contains a song with the following lines:

He never came from Brighton with a 'Season'

And stood up all the way without a place

While hoards of Russian Yids were talking treason

And shoving greasy elbows in his face.

He never knew the folk across the Jordan,

He'd never heard of German-Palestine;

And so he never met Sir Gordon Gordon

Whose name before the war was Hoggenschein.

The refrain is as follows:

Old Man Adam!

Lucky, lucky Adam!

Oh, what a time he had before the Fall!

Tho' of pork there's not a dam,

We've got too much Abra-ham,

But Adam never 'ad 'em at all!

The final scene echoes the transformation scene familiar everywhere in popular theatre except that in this case, where a ballroom becomes a hospital ward for wounded soldiers, it is reality rather than magic that provides the agency. It originally contained a song entitled 'If I Had Known'. This was eventually cut from the show, although not at the censor's insistence, but the fact that it was written at all indicates 
just how far musical theatre had moved from its fin de siècle celebration of metropolitan 'gaiety' and its powers of seemingly universal accommodation.

If I had been Napoleon and known what I know now!

I'd not have worried Wellington at all,

But merely biffed old Blucher and all his German crew,

And should not then have ridden for a fall.

There would have been no Bismarck, no lost Alsace Lorraine,

No Paris siege, no Waterloo for me,

I should have joined with Britain and blotted out Berlin,

And then the world from Kultur had been free.

If I had known what I know now,

There would have been no German swine,

No sausage herr, no sauerkraut frau

No Potsdam Hohenzollern line

No royal hog, nor royal swine

If I had been Napoleon and I had known what I know now.

A later verse expresses the sentiment that Muslims are preferable to Germans and adds 'I still could murder Jews in Holy Land', a comment which once again illustrates how the idea of the 'alien' rendered Jewish and German identities virtually interchangeable. ${ }^{22}$ Nothing so aggressively charged could be found in musical theatre culture of the earlier period in either site, not even in the representation of black and Asian cultures, where there was more room for ambiguity and nuance, especially in the context of gendered relationships and the sexual frisson that often passed between races in this highly controlled version of 'safe pleasure'. ${ }^{23}$ 
Representations in a similar vein could be found everywhere in revue in the war years-in Buzz Buzz (1921), for example, an André Charlot show which starred Gertrude Lawrence, and Albert De Courville's show Push and Go (1915). The latter included a particular assault on those thought to be pro-German. Four figures got up to look like George Bernard Shaw, Keir Hardie, Ramsey MacDonald and Dr Lyttleton are paraded before the audience by a narrator:

They're a bunch of anti-patriots.... This one [Shaw] says that England is the foul aggressor in the war and the neutrality of Belgium was all rubbish. Jolly little fellow, isn't he? This one [Hardie] is going to Heligoland when we've wound up the watch on the Rhine. This one [Macdonald] hates England to strike hard for justice and this one [Lyttleton] calls us to give up Gibraltar and love the dear Germans and their frightfulness. ${ }^{24}$

Scene 8 of the show was an anti-German scene where a German man and his two sons sang a song entitled 'We hate the English'. In one of the bizarre juxtapositions that typified revue, this was followed by another singer performing a number entitled 'My Snake Charming Girl'. That in turn led to a patriotic 'battleship scene' and a rousing rendition of 'Don't Forget the Navy' where British Sailors are 'the true blue boys...keeping you safe and sound'-and that by 'the Zeppelin scene' where zeppelins were shaped like giant sausages, and German sausage becomes 'ze greatest product of German genius und German Kultur' ${ }^{25}$ Admiral Von Tirpitz and Field Marshall Von Hindenburg later appear in this sketch — the latter as a dachshund.

\section{'Now what do the Yellow Shirts stand for'? Not staging National Socialism}

As has already been seen in earlier chapters, Germany was to return to West End stages in the West End in the 1920s, where it figured as part of exchange culture, 
typically disguised as 'Austria' and constructed in terms of romantic, idealising retrospection. ${ }^{26}$ Others forms of musical theatre outside of operetta, however, continued to evoke the contemporary event, remaining engaged with modern style, at the same time as retaining the status of a culture that above all 'entertained'. There were obvious strains and contradictions in this position. Musical comedy, for example, although often patriotic, was usually eager to withdraw from anything that compromised its status as entertainment and sometimes received institutional and public condemnation when it was perceived to have failed in this respect. The later 1930s put particular strain on that detached status, especially in relation to the stage representation of modern Germany.

The classic example here would be the truly bizarre Swing Along-not a show that set out to be deliberately provocative but, rather, one which illustrated the pitfalls of rendering the politics of the 1930s as entertainment in the standard musical comedy format. Written by Guy Bolton, Fred Thompson and Douglas Furber and produced by Firth Shepherd at the Gaiety, this 1936 musical opened as a fairly nondescript and highly Americanised song and dance show-the character 'Miami' sings a song entitled 'Tin Can' which contains the lines 'You are after my fruit/And there isn't a galoot that a girl can trust!' Set in Monte Carlo and Paris, it appears to be a fairly standard story of fashionable society, love and marriage until, that is, familiarity is severely disrupted by the appearance of two competing political factions, the 'Yellowshirts', led by a character called Xabiski-'a stink in the nostrils of the civilized world' - and the 'Noshirts', led by Torrero. Thereafter traditional components of musical comedy narratology—a love triangle, mistaken identity, cross dressing and so on—attempt to collaborate with a joke version of ideological conflict, except that in this case even the notional assimilation of contemporaneity as fun and 
games is permanently under threat of total collapse. Singing and dancing here collide with fascist marches, salutes and an assassination attempt to produce a badly misshapen misfit — a grotesque combination of gaiety and terror and one of the few musical comedies to contain machine gun fire. Certainly, in retrospect, the show seems to operate on improbable ground and yet it ran for 311 performances in 1936, making it one of the most successful West End musical comedies of the 1930s. As strange as it appears now, audiences must at one time have tapped their fingers and feet to songs like the following:

When you see my manly chest,

In a simple under-vest,

A salute is due,

For it is my uniform;

I'm a No-Shirt and we're tough

And we can't go far enough,

For a barricade,

Or a pretty maid to storm.

We are here to tear to rags

And trample in the dirt,

All the craven scally-wags

Who wear the yellow shirt.

And if you don't think our way

You will live to rue the day

When you see us in our glory

Swinging, singing in the fray. 
In some ways reminiscent of P. G. Wodehouse's treatment of the Blackshirts in such fictions as The Code of the Woosters (1937), Swing Along, however, was not entirely a comic satire, but, rather, a musical show collapsing against the pressure of rendering the rise of fascism as entertainment - a much less knowing version of the kind of project mounted by Mel Brooks later in the 1968 film The Producers. Interestingly, and in stark contrast to Brooks's film of course, it did not specifically refer to National Socialism at all, except in one part of the original script where the following exchange takes place as a character called Georges is being schooled to impersonate the Fascist leader Xabiski:

Georges: Oh I suppose it will have to do. Now what do the Yellow Shirts stand for?

Maxi: If they stand for Xabiski they'll stand for anything.

Georges: What?

Maxi: Now, now can't you boys take a joke?

Georges: No.

Maxi: Of course not. I forgot the Olympic games are over.

Georges: Well, we Yellow Shirts love our chief. ${ }^{27}$

But the line about the 1936 Olympics attracted the censor's eye and had to be cut, thus removing the one explicit reference to German fascism in the entire show. Hitler's Germany in this instance was everywhere evoked but had no substance, not even the flimsy substance of the mystification 'Austria'. The show's determined attempt to be 'contemporary' forced it into a vacuum, the real subject of its narrative becoming reduced to the ghost-like presence of a Derridean hauntology, now called, ironically enough, 'Paris', which is where much of the show was set. 
[INSERT ILLUSTRATION 15]

[CAPTION] No shirts on parade in Swing Along, 1929

For the most part, however, 1930s Germany remained absent from musicals in London. There was just one further attempt to frame fascism on the West End stage as musical, right on the brink of World War Two, and that was The Dancing Years, the last of a sequence of famously extravagant successes at Drury Lane written and starring Ivor Novello. In this fascinating show, Novello, often criticised for producing silly romances of the 'Ruritanian' kind, in fact makes a bold bid for contemporaneity. Although The Dancing Years does sign up to many of the standard romantic conventions of operetta, it manages to combine conformity with stark transgressions. It is the relatively successful blending of these elements that makes Novello, in this show and others, Glamorous Nights (1935) for instance, stand out as a musical theatre innovator. $^{28}$

The Dancing Years opens in a setting entirely unlikely for operetta: a prisoner is being interrogated by the military in what was once a Viennese palace. No longer the home of aristocratic glamour, 'Vienna' has been commandeered by a brutalising military authority. The invading force is represented by Herr Ober Lieutenant Goetzer, at the beginning of the show leading a final questioning of 'Rudi' Kleber before he signs the latter's death warrant. Kleber is a once-famous composer of operetta, now imprisoned for illegally helping his friends to leave the country. 'You've made them sweep the streets', Kleber declares, passionately, 'delicate, sensitive men and women have swept the filth from the streets-you've taken their living away from them-you've tried to take away my living'. ${ }^{29}$ Circumnavigating the fact that German operetta, in its Aryan formulation, thrived under National Socialism, 
The Dancing Years, then, dramatises the death of musical theatre at the hands of political extremism and, indeed, takes something of a stand, albeit an indirect one, against the treatment of Jews working in the industry.

At which point the play moves backwards in time to a golden age where Germans (as Austrians) were Anglophiles. They 'adore' English food and a minor character, Lilli, a performer in musical theatre, loves everything English. 'They asked me to go to England to play The Merry Widow', she claims, 'but I was too young'. That reference to cultural transfer is not isolated. Indeed, The Dancing Years contains more references to musical theatre exchange than any show of the whole period. In one scene Rudi is asked by George Edwardes to take his show Lorelei to London (this being the first and only appearance of a fictionalised George Edwardes in a stage musical comedy or operetta). Greta, one of the female leads, moves to London to perform in musical theatre. When she returns to attend Rudi's gala in Vienna, the expectancy is that she will perform 'one of those innocuous little musical comedy songs that are so popular in England and nowhere else'-a curious but quite typical erasure of the once global popularity of these shows. ${ }^{30}$ Interestingly, for Novello cultural exchange between England and Germany becomes one of the defining elements of his golden age.

One of the main ways in which the heyday of operetta is rendered, however, harks back to the spectacular renditions of Germany as 'Austria' referred to in chapter six. At the centre of The Dancing Years is the play within a play device that stages a potted performance of Lorelei complete with fifty boys and girls singing Tyrolean folk songs. It looks at first sight as if Novello has pulled off a stylish imitation of the narrative device standard in 1920 s and 30 s operettas where an evocation of contemporaneity leads to a fast retreat. But that would be something of a 
simplification. For the opening scene of The Dancing Years is not, in fact, retreated from at all. Instead it becomes a framing device that remains in place throughout the show, a show which inevitably must return to the present day where Rudi, one-time star composer at the Theater an der Wien, remains in prison awaiting execution. If by exercise of intervention from his true love, Mitzi-now married to Prince Metterling - Rudi manages to escape death, the show nevertheless manages to retain a sharp edge. Here the dark forces of fascism destroy not just the golden age of musical theatre, but an entire culture visualised as all that is vital and romantic in life.

Novello tried to militate against controversy in this show, not least by avoiding any direct reference to National Socialism or Hitler. This notwithstanding, the implication of The Dancing Years was entirely transparent, so much so that this Drury Lane spectacular raised familiar concerns about the separation of domains and the rightful place of popular entertainment. The British library file for playscripts contains a fascinating letter of complaint about The Dancing Years, undated, unsigned and addressed to the Lord Chamberlain, St James Palace, SW1. It reads:

My lord Chamberlain, A very large section of the audience at Drury Lane last Thursday were very much surprised that you passed the Anti-Nazi scene in 'The Dancing Years'....It undoubtedly pleased a certain section of the audience and was wildly applauded, but it jarred others and some of the people booed-or tried to boo. It seems a pity that politics are allowed in such plays. This letter is sent you in all good faith and from number of people who while being quite sympathetic resent the inclusion of scene 6 in 'The Dancing Years'. 31

In reality, as this chapter has shown, these shows always operated within a political domain, an engagement particularly clear in a representation of Germans and Germany that remained firmly British right across the period. What was new here was 
that in imagining modern Germany in terms of the end of gaiety and romance, Novello had dared to step outside the safe and highly circumscribed world where the political was convened, and often obscured, in carnival terms as innocent good fun. Of course, Novello remained an entertainer, but for some of his audience at least, this transgression was too much, a step too far which threatened to break the ago-old but always unstable contract between popular musical theatre and harmless diversion.

\section{Notes}

${ }^{1}$ See Geppert and Gerwarth, Wilhelmine Germany and Edwardian Britain, 2. They quote E. A. Brayley Hodgetts, a former Reuters correspondent in Germany. Writing just three years before the outbreak of the war, during the second Moroccan crisis of 1911, Hodgetts observed that 'the most salient feature of Berlin society is open and undisguised Anglomania', suggesting that everybody in the Kaiserreich 'tried to look English...from the Emperor downwards', an extreme view that should be treated with caution. See E. A. Brayley Hodgetts, The House of Hohenzollern: Two Centuries of Berlin Court Life (London, 1911), 410-11.

${ }^{2}$ See the exchange between Rozanne, a rising performer in Coward's play and the producer, Hobson, about a new show written by 'Franz Knuhlman'. On hearing the news Rozanne exclaims, 'Knuhlman! That will be wonderful, won't it?' Hobson replies, 'In my opinion it's the finest he's ever written-better even than "Love from Vienna".' Nöel Coward, Operette (London: Heinemann, 1938), 94.

${ }^{3}$ John R. Davis, The Victorians and Germany (Bern: Peter Lang, 2007), 9.

${ }^{4}$ Davis, The Victorians and Germany, 28.

${ }^{5}$ E. A. Baughan, 'The Drama of the Year', The Stage Year Book 1911. 
${ }^{6}$ Frank E. Washburn Freund, 'The German Theatrical Year', Stage Year Book 1909.

Of course, Shaw had been a strong critic of contemporary musical theatre.

${ }^{7}$ The Play Pictorial 20/121, 1912.

${ }^{8}$ E. A. Baughan, 'The Drama of the Year', Stage Year Book 1913

${ }^{9}$ The Sunday Times, 2 June 1896.

${ }^{10}$ The Times, 13 January1896.

${ }^{11}$ The following, a small sample from the register of Lord Chamberlain's plays in the British Library, indicates something of the energy devoted to protecting the Emperor's image. The Ballet Girl, a 'musical play' applying for license in March 1897, was required to 'omit in Representation all personal References to the German Emperor (British Library, add. ms. 61952, 30 December 1908). Send Him Victorious, performed at the Prince's over the Christmas season in 1908, was given a license that 'only applies to a copy revised and altered in compliance with the requirements of the Lord Chamberlain. (1) No character in the piece to represent the German Emperor. (2) No reference to a political conspiracy to promote a war between England and Germany' (British Library, add. ms. 53708, 30 March 1897). The license for The Glorious Day, a play performed at the Elephant and Castle in 1915, was 'granted on the understanding that the characters representing the Emperor and Crown Prince in the last scene are not made up to represent the German Emperor and the Crown Prince of Germany’ (British Library, add. ms. 61954, 12 February 1915).

12 James T. Tanner, Alfred Murray, The Messenger Boy (British Library: LCP, 1907).

${ }^{13}$ Illustrated London News, 27 October 1906.

${ }^{14}$ George Grossmith Jnr., L.E. Berman, The Girls of Gottenberg with lyrics by Adrian Ross and Basil Hood (British Library: LCP, 1907).

${ }^{15}$ The Illustrated London News, 2 May 1896. 
${ }^{16}$ The Times, 16 May 1907.

${ }^{17}$ Otte, Jewish Identities in German Popular Entertainment, 173.

${ }^{18}$ The Stage Year Book 1916.

${ }^{19}$ For all the anti-Semitism evident in wider late Victorian and Edwardian culture at the turn of century and especially in the lead up to the Alien Immigration Act (1905), there was surprisingly little anti-Semitism in the script of fin de siécle West End musical theatre - a reflection no doubt of the number of Jews, in London as in Berlin, who worked in musical theatre at all levels from production and performance through to finance. See Platt, Musical Comedy on the West End Stage, 78-82.

${ }^{20}$ Arthur Wimperis, As You Were, (British Library: LCP, 1918).

${ }^{21}$ Quoted in David Glover, Literature, Immigrations, Diaspora in fin de siécle England: A Cultural History of the 1905 Aliens Act (Cambridge: Cambridge University Pres, 2012). Glover quotes Rudoph Rocker, The London Years, trans. Joseph Leftwich (London: Robert Anscombe, 1956), 156.

${ }^{22}$ Wimperis, As You Were.

${ }^{23}$ See Platt, Musical Comedy on the West End Stage, 74-8.

${ }^{24}$ Albert De Courville, Wal Pink, Push and Go (British Library: LCP, 1915). None of these figures were genuinely pro-German. The least known today, Dr Lyttleton, Head Master of Eton, preached an unfortunate sermon where he argued that an act of generosity, internationalising Gibraltar, would help make Germany feel included in what he called 'the comity of nations'. The Spectator called him mistaken, 'but no pro-German' (The Spectator, 3 April 1915).

${ }^{25}$ De Courville, Pink, Push and Go.

${ }^{26}$ See chapter six in this collection [000-000]. 
${ }^{27}$ Guy Bolton, Fred Thompson, Douglas Furber, Swing Along (British Library, LCP, 1936).

${ }^{28}$ Glamorous Nights, a show that works similarly in some ways to Dancing Years, also has a political frame, but here the site of the potential dictatorship/empire is a fictional one, Krasnia. The show does, however, contain a reference to Mussolini 'enthusiastically cheered.... at a meeting of three hundred thousand fascists'. The allusion is mediated by the fact that it features at a radio broadcast of the news. Ivor Novello, The Glamorous Years, (British Library: LCP, 1935).

${ }^{29}$ Ivor Novello, The Dancing Years (British Library: LCP, 1939).

${ }^{30}$ Novello, The Dancing Years.

${ }^{31}$ This letter is currently tucked away inside the play script for The Dancing Years in the Lord Chamberlain's plays collection. 